\title{
KUALITAS PELAYANAN KANTOR KECAMATAN TERHADAP KEPUASAN MASYARAKAT DOLOK BATU NANGGAR DI KABUPATEN SIMALUNGUN
}

\author{
Poltak Pardamean Simarmata ${ }^{1)}$, Doris Yolanda Saragih ${ }^{2)}$ \\ Hengki Mangiring Parulian Simarmata ${ }^{3}$ ) \\ ${ }^{1}$ Manajemen, Sekolah Tingga Akuntansi Manajemen Indonesia \\ email: poltak.pardamean@sbm-itb.ac.id \\ ${ }^{2}$ Komputer Akuntansi, Politeknik Bisnis Indonesia \\ email: dorisyolandasaragih@gmail.com \\ ${ }^{3}$ Manajemen Administrasi Perkantoran, Politeknik Bisnis Indonesia \\ email: hengkisimarmata.mm@gmail.com
}

\begin{abstract}
Service quality is one of the most important in government services because society will give good value from the services of their community. The purpose of this study was to determine the magnitude of the influence of the quality of public services on community satisfaction in Simalungun district, This study used a qualitative method and the data was collected by using questioner and observation method. The sample is using 100 samples with random sampling. The data collected then tested the validity and reliability and then analyzed using linear analysis using SPSS. From this study, it can be seen that there is a positive and significant influence on service satisfaction in the Dolok Batu Nanggar sub-district of 53.8\% while $46.2 \%$ is influenced by other variables not examined in this study. For further research can be develoedp using relationship management or loyalty variable.
\end{abstract}

Keywords : Service Quality, Satisfaction.

\section{PENDAHULUAN}

Pemerintah pada hakikatnya bekerja sebagai pelayan publik untuk memenuhi kebutuhan masyarakat. Menurut Keputusan Menteri Pemberdayaan Aparatur Negara No 63/KEP.M.PAN/7/2003 bahwa pemerintah memberikan pelayanan untuk keperluan masyarakat yang mempunyai kepentingan sesuai dengan aturan pokok dan tata cara yang ditetapkan. Layanan publik di tingkat kelurahan yang diberikan sebagai contoh layanan administrasi seperti pembuatan surat, pengurusan KTP, Pengurusan kartu keluarga, surat keterangan tinggal sementara, pembuatan akte lahir, pengantar pembuatan SKCK, Keterangan pembuatan Akta Tanah, Surat Kematian, dan administrasi lainnya.

Sebagai pelayan publik pemerintah harus mampu memberikan pelayanan yang baik kepada masyarakat sehingga mendapatkan tingkat kepercayaan yang tinggi dari masyarakat. Salah satu hal yang perlu diperhatikan adalah kualitas pelayanan publik. Untuk meningkatkan pelayanan publik, pemerintah perlu memperhatikan tingkat kepuasan masyarakat atas pelayanan yang diberikan. Karena kualitas pelayanan memiliki hubungan yang erat dengan kepuasan masyarakat. Jika kepuasan masyarakat tinggi maka menggambarkan kinerja pemerintah baik atau sebaliknya jika kepuasan masyarakat rendah akan menjadi citra buruk bagi pemerintah.

Oleh sebab itu setiap aparatur sipil negara (ASN) bertanggung jawab dan harus mampu memberikan pelayanan yang baik agar meningkatkan kepercayaan masyarakat kepada pemerintah [1]. Pemerintah sebagai pelayan publik harus bertanggung jawab dan mampu memberikan yang terbaik kepada masyarakat demi menjaga kepercayaan 
masyarakat kepada pemerintah [2].Pelayanan publik yang dilakukan oleh aparatur sipil negara harus mampu bekerja secara efektif, efisien dan produktif [3].

Pemerintah daerah yaitu kelurahan merupakan unit terkecil dari pemerintahan yang dekat dengan masyarakat. Di dalam fungsi dan tugasnya kelurahan harus mampu memenuhi segala kebutuhan administrasi masyarakat yang ada di wilayahnya. Pelayanan administrasi yang diberikan seperti pendaftaran penduduk, pencatatan sipil, pengelolaan informasi untuk pelayanan dan pembangunan daerah. Kelurahan diharapkan mampu memberikan pelayanan yang baik dan optimal kepada masyarakat yang ada di wilayahnya dengan ramah, sopan dan efektif.

Kecamatan Dolok Batu Nanggar merupakan salah satu kecamatan yang berada di Kabupaten Simalungun Sumatera Utara. Kelurahan ini terletak di antara Kota Serbelawan dan Perkebunan PTPN IV Dolok Ilur Kabupaten Simalungun. Berdasarkan data yang diperoleh dari Kantor Kecamatan jumlah kelurahan yang ada di Kecamatan Dolok Baru Nanggar adalah sebagai berikut :

Tabel 1 Kelurahan di Kecamatan Dolok Batu Nanggar

\begin{tabular}{|c|l|}
\hline N0 & Nama Kelurahan \\
\hline 1 & Aman Sari \\
\hline 2 & Bah tobu \\
\hline 3 & Bahung Huluan \\
\hline 4 & Bahung Kahean \\
\hline 5 & Bandar Selamat \\
\hline 6 & Dolok Ilir 1 \\
\hline 7 & Dolok Ilir II \\
\hline 8 & Dolok Kataran \\
\hline 9 & Dolok Mainu \\
\hline 10 & Dolok Merangir 1 \\
\hline 11 & Dolok Merangir II \\
\hline 12 & Dolok Tenera \\
\hline 13 & Kahean \\
\hline 14 & Padang Mainu \\
\hline 15 & Serbelawan \\
\hline
\end{tabular}

\begin{tabular}{|c|c|}
\hline 16 & Silinduk \\
\hline Sumber: Data Kecamatan Dolok Batu \\
Nanggar
\end{tabular}

Pelayanan administrasi merupakan salah satu tugas yang dilakukan di Kecamatan Baru Nanggar. Di tingkat kelurahan masyarakat masih sering mengeluhkan pelayanan yang diberikan tidak optimal. Keluhan yang disampaikan masyarakat seperti proses pembuatan surat keterangan yang dianggap lambat dan waktu penyelesaian terlalu lama. Di samping itu masyarakat juga mengeluhkan fasilitas kantor yang tidak mendukung kinerja aparatur sipil negara sehingga proses pengurusan administrasi memakan waktu yang lama seperti pembuatan kartu keluarga, pembuatan E-KTP dan lainnya.

Pelayanan yang kurang menyebabkan berkurangnya tingkat kepercayaan masyarakat terhadap kinerja pegawai di Kecamatan Dolok Batu Nanggar. Pelayanan yang kurang juga disebabkan karena sumber daya manusia yang bekerja kurang profesional. Oleh karena itu perlunya peningkatan kualitas layanan terhadap para pegawai dalam melayani masyarakat. Berdasarkan latar belakang diatas maka penulis tertarik untuk meneliti Pengaruh kualitas pelayanan kantor kecamatan terhadap kepuasan masyarakat Dolok Batu Nanggar di Kabupaten Simalungun

Rumusan Masalah

Berdasarkan latar belakang penelitian diatas maka rumusan masalah dalam penelitian ini adalah apakah terdapat pengaruh kualitas pelayanan kantor kecamatan terhadap kepuasan masyarakat Dolok Batu Nanggar di Kabupaten Simalungun Tujuan Penelitian

Tujuan dari penelitian ini adalah untuk mengetahui seberapa besar pengaruh kualitas pelayanan kantor kecamatan terhadap kepuasan masyarakat Dolok Batu Nanggar di Kabupaten Simalungun.

Manfaat Penelitian

Penelitian ini memberikan beberapa manfaat kepada berbagai pihak yaitu :

1. Bagi Penulis 
Untuk meningkatkan pemahaman dan ilmu pengetahuan di bidang manajemen dan mampu untuk melakukan penerapan ilmu manajemen di Kantor Pemerintahan

2. Bagi Kantor Kecamatan Dolok Batu Nanggar menjadi masukan agar dapat memberikan pelayanan yang lebih baik lagi kepada masyarakat di Kabupaten Simalungun dan memberikan perubahanperubahan pelayanan.

3. Bagi Peneliti Lain

Sebagai bahan referensi di bidang ilmu manajemen dan dapat memperluas pemahaman tentang kualitas pelayanan di kantor pemerintahan.

\section{Tinjauan Pustaka}

Kualitas Layanan

Pelayanan publik merupakan hal yang sangat penting dan dibutuhkan masyarakat didalam menciptakan tertib administrasi. Oleh karena itu kualitas pelayanan merupakan hal penting yang harus dilakukan oleh pemerintah sebagai pelayan publik. Dengan adanya kualitas layanan publik yang baik maka dapat menciptakan kepuasan dan citra positif kepada pemerintah.

Menurut Kotler dan Keller dalam Simarmata [4] kualitas layanan merupakan total dari keseluruhan karakteristik dari produk atau layanan yang ditawarkan kepada masyarakat guna memenuhi kebutuhan dan keinginannya. Sama halnya dengan Tjiptono dalam Trisusanti [5] bahwa pelayanan merupakan perbuatan atau tindakan yang dilakukan oleh produsen kepada konsumen yang bersifat intagible. Pelayanan yang berkualitas juga dijelaskan oleh Sriwidodo dan Indriastuti sebagai bentuk dari penilaian konsumen atas layanan yang diterima dibandingkan dengan layanan yang diharapkan. Kualitas layanan dipengaruhi oleh dua faktor yaitu expected service dan perceived service sedangkan menurut Lehtinen dalam Eliza bahwa kualitas layanan dibagi menjadi process quality dan output quality[1]

Kualitas layanan merupakan bentuk dari pemenuhan kebutuhan dan keinginan masyarakat serta adanya ketepatan dalam penyampaian jasa. Oleh sebab itu kualitas pelayanan juga disebut sebagai keunggulan dalam pemenuhan harapan dan realita [6]. Kualitas layanan menurut Simarmata sebagai bentuk dari evaluasi atas jasa yang diterima oleh masyarakat secara keseluruhan layanan tersebut mencakup pada tangibles, reliability, responsiveness, assurance, dan empathy sebagai tolak ukurnya [7].

Dimensi Mengukur Kualitas Pelayanan

Pengukuran kualitas pelayanan dikenal dengan istilah SERVQUAL Metode ini di kembangkan oleh Parasuraman yang di dasarkan pada Gab Model. Sedangkan peneliti lain seperti Othman dan Owen menggunakan CARTER sebagai alat ukur kualitas jasa yaitu Compliance, assurance, reliability, tangible, empathy dan responsiveness[8].

Dimensi kualitas jasa menurut kotler dalam Eliza terdapat lima determinan yaitu 1) Kemampuan melakukan jasa yang dijanjikan (reliability); 2) Kemampuan membantu dan memberikan jasa dengan baik dan cepat (responsiveness); 3) Pengetahuan, kesopanan ASN untuk menimbulkan keyakinan dan kepercayaan (confidence); 4) Kepedulian, perhatian bagi masyarakat; 5) Penampilan personel, fisik, peralatan dan media komunikasi [1]. Sedangkan menurut

Menurut Simarmata dimensi kualitas pelayanan terdiri dari

1. Bukti fisik, merupakan fasilitas yang ada di ruangan, penampilan dari pemberi layanan, peralatan yang digunakan dalam melayani

2. Kehandalan, merupakan kemampuan dari pemberi layananan didalam memberikan apa yang telah dijanjikan kepada konsumen

3. Daya tanggap merupakan kesiapan dari pemberi layanan yang cepat dan bertanggung jawab

4. Jaminan, merupakan kompetensi yang dimiliki pemberi layanan, pengetahuan yang dimiliki didalam memberikan layanan.

5. Kepedulian merupakan adanya kepedulian dan keprihatinan kepada penerima layanan. 
Untuk mengukur kualitas layanan, dimensi ini juga dipakai oleh Sriwidodo \& Inriastuti dan Trisusansi [5], [8]. Dalam penelitian ini dimensi yang digunakan untuk mengukur kualitas pelayanan terhadap masyarakat adalah SERVQUAL yaitu bukti fisik, kehandalan, daya tanggap, jaminan dan kepedulian.

\section{Kepuasan Masyarakat}

Dalam Kotler kepuasan merupakan perasaan bahagia, senang,atau senang dan sedih atas realita jasa yang diterima dibandingkan dengan jasa yang diharapkan [4]. Kepuasan pelanggan juga dijelaskan Kotler sebagai perbandingan antara hasil dengan harapan sehingga untuk menciptakan kepuasan perlu diciptakan sesuatu yang bernilai lebih [5].

Menurut Eliza bahwa kepuasan merupakan perasaan senang atau kecewa setelah membandingkan harapan dengan realitas. Jika kinerja memenuhi harapan masyarakat maka masyarakat akan puas dan jika kinerja melebihi harapan maka masyarakat akan merasa sangat puas [1]

Keinginan pelanggan merupakan bentuk dari keyakinan sebelum mencoba atau membeli suatu produk yang di jadikan standar dalam menilai kinerja[8]. Adapun faktorfaktor yang mempengaruhi kepuasan pelanggan yaitu karena (1) Faktor pelayanan; (2) Harga produk atau jasa; (3) Kualitas produk atau jasa; (4) Lokasi; (5) Merek; (6) Design.

Kualitas pelayanan dan kepuasan pelanggan saling berhubungan semakin tinggi kualitas layanan yang di persepsikan akan meningkatkan kepuasan dari pemakai layanan. Oleh karena itu puas atau tidak puasnya masyarakat dipengarugi oleh perbandingan antara harapan dengan kinerja pelayanan yang diberikan. Jika pelayanan yang diberikan sudah sesuai dengan harapan maka pelayanan tersebut dikatakan sebagai pelayanan yang berkualitas dan jika pelayanan yang diberikan tidak sesuai dengan harapan maka pelayanan tersebut dianggap tidak baik atau buruk [9]

Dimensi Mengukur Kepuasan Masyarakat
Dimensi yang digunakan untuk mengukur kepuasan masyarakat adalah (1) Munculnya loyalitas pelanggan sehingga pelanggan sulit berpindah ke pesaing; (2) Pelanggan akan melakukan pembelian ulang; (3) Meningkatnya pembelian; (4) Meningkatnya promosi gratis [10]

Sedangkan menurut Roisah dan Roana dalam Simarmata untuk mengukur kepuasan pelanggan adalah (1) Kepuasan terhadap produk; (2) Kepercayaan terhadap produk; (3) Emosional; (4) Pilihan produk dan jasa; (5) word of mouth. Sedangkan dalam penelitian Simarmata sendiri untuk mengukur kepuasan pelanggan dengan menggunakan dimensi (1) Kenyamanan yang dirasakan, (2) Kesesuaian harga; (3) Kepuasan; (4) Keinginan untuk merekomendasikan.

Dalam penelitian ini dimensi yang digunakan untuk mengukur kepuasan masyarakat adalah kenyamanan yang dirasakan, kepuasan atas layanan kecamatan; biaya yang dikenakan, keinginan untuk berbicara positif tentang kinerja pelayanan.

Berdasarkan hasil kajian teori yang telah dijelaskan maka hipotesis penelitian ini adalah Ho: Tidak terdapat pengaruh yang signifikan antara layanan kecamatan terhadap kepuasan masyarakat Dolok Batu Nanggar di Kabupaten Simalungun

$\mathrm{H} 1$ : Terdapat pengaruh yang signifikan antara layanan kecamatan terhadap kepuasan masyarakat Dolok Batu Nanggar di Kabupaten Simalungun.

\section{METODE PENELITIAN}

Penelitian ini menggunakan metode desktiptif dan verifikatif. Metode deskritif digunakan untuk mengetahui gambaran secara keseluruhan mengenai kualitas pelayanan yang diberikan kantor kecamatan terhadap masyarakat Dolok Baru Nanggar Kabupaten Simalungun. Metode verifikatif digunakan untuk mengetahuo pengaruh variabel layanan kecamatan (X) terhadap kepuasan masyarakat (Y).

Lokasi Penelitian

Penelitian ini dilakukan di kecamatan Dolok Batu Nanggar Kabupaten Simalungun, Sumatera Utara 
Populasi dan Sampel

Populasi dalam penelitian ini merupakan seluruh masyarakat yang berada di kecamatan Dolok Batu Nanggar Kabupaten Simalungun khususnya yang berada di Kelurahan Silinduk. Jumlah populasi sebanyak 2.293 jiwa. Sedangkan sampel dalam penelitian ini adalah objek yang dianggap memenuhi syarat dan karakteristik yang sesuai dengan penelitian yaitu masyarakat yang sudah memiliki kartu tanda pengenal penduduk (KTP) dan teknik dalam pengambilan sampel menggunakan teknik non probability dengan cara purposive sampling. Jumlah sampel yang digunakan adalah 100 orang dengan menggunakan rumus Slovin adalah sebagai berikut :

$$
\begin{aligned}
\mathrm{n} & =\frac{N}{1+N e^{2}} \\
& =\frac{2.293}{1+2.293(0,10)^{2}} \\
& =\frac{2.293}{22,94} \\
& =99,9
\end{aligned}
$$

Jenis dan Sumber Data

Data yang digunakan didalam penelitian ini adalah data primer dan data sekunder. Data primer merupakan data yang diperoleh langsung dari objek penelitian yaitu melalui hasil kuisioner, observasi langsung kelapangan dan melakukan wawancara. Data primer dari hasil penyebaran kuisioner diperoleh dari masyarakat yang sedang melakukan pengurusan administrasi dikantor kecamatan Dolok Batu Nanggar Kabupaten Simalungun. Observasi lapangan dilakukan dengan berkunjung ke kantor kecamatan dan kantor kelurahan.

Data sekunder yang digunakan berupakan data-data yang diperoleh dari kantor kecamatan, studi pustaka dari bukubuku manajemen, jurnal nasional dibidang manajemen.

Teknik Analisis Data

Teknik dalam menganalisis data menggunakan uji validitas, uji reliabilitas, uji hipotesis, uji t parsial, dan uji f simultan.Uji validitas digunakan untuk mengukur ketepatan suatu instrimen dalam mengukur apa yang ingin diukur dimana nilai yang digunakan agar diyatakan valid adalah nilai diatas angka 0.30. Uji reliabilitas adalah uji yang digunakan untuk mengetahui tingkat konsistensi dari alat ukur dimana menggunakan nilai Cronbach Alpa yang diinginkan lebih besar sama dengan 0.6 Data dioleh dengan menggunakan analisis linear sederhana dengan menggunakan SPSS versi 23. Data dikumpulkan, kemudian diolah dan dianalisis agar mudah didalam menarik kesimpulan didalam pengambilan keputusan.

\section{HASIL DAN PEMBAHASAN}

Analisis regresi linier sederhana didasarkan pada hubungan fungsional ataupun kausal satu variabel bebas dengan satu variabel terikat. Dimana dalam penelitian ini variabel $\mathrm{X}$ (variabel bebas) Kualitas pelayanan dengan dimensi tangible, reliability, responsiveness, assurance dan empathy terhadap variabel Y (variabel terikat) yaitu kepuasan masyarakat.

Perhitungan statistik dalam analisis regresi linier sederhana yang digunakan dalam penelitian ini adalah dengan menggunakan bantuan program komputer SPSS for Windows versi 23.

Tabel 3.1 Hasil Analisis Regresi Linear Sederhana

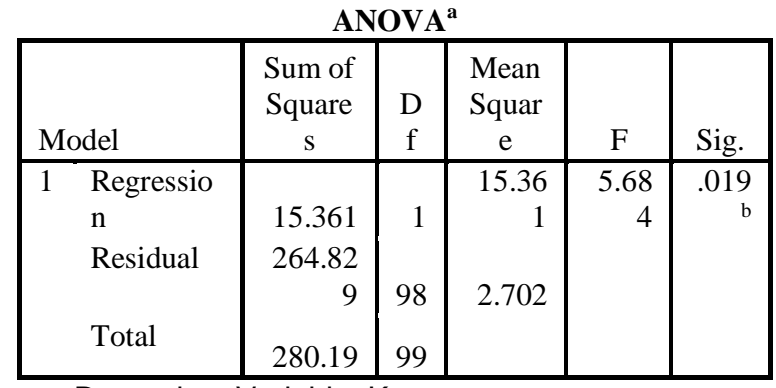

a. Dependent Variable: Kepuasan

b. Predictors: (Constant), Pelayanan

Sumber: Data Primer Diolah

Dari tabel 3.1 dapat dijelaskan hasil perhitungan statistik nilai $\mathrm{F}$ hitung $=5.684$ dengan taraf signifikan hitung 0.019 . Berdasarkan perolehan nilai Sig hitung $0.019<$ Sig tabel 0.05, maka dapat disimpulkan bahwa 
variabel bebas (independen) yaitu kualitas pelayanan mempunyai pengaruh yang positif dan signifikan terhadap variabel terikat (dependen) yaitu kepuasan masyarakat.

Dengan demikian, $\mathrm{H}_{0}$ yang menyatakan bahwa " Ho Tidak terdapat pengaruh yang signifikan antara layanan kecamatan terhadap kepuasan masyarakat Dolok Batu Nanggar Kabupatan Simalungun" ditolak, dan $\mathrm{H}_{1}$ yang menyatakan "Terdapat pengaruh yang signifikan antara layanan kecamatan terhadap kepuasan masyarakat Dolok Batu Nanggar di Kabupaten Simalungun” diterima.

\section{Koefisien Determinan}

Koefisien determinan menunjukkan perubahan nilai variabel dependen yang disebabkan oleh perubahan variabel independen. Koefisien determinan $\left(\mathrm{R}^{2}\right)$ dimaksudkan untuk mengetahui tingkat ketepatan paling baik dalam analisa regresi hal yang ditujukan oleh besarnya koefisien determinasi $\left(\mathrm{R}^{2}\right)$ antara 0 (nol) dan 1 (satu). Jika koefisien determinasi $\left(\mathrm{R}^{2}\right)$ sama dengan nol, maka variabel independen sama sekali tidak berpengaruh terhadap variabel dependen. Apabila koefisien determinan semakin mendekati satu, maka dapat dikatakan bahwa variabel independen berpengaruh terhadap variabel dependen.

Tabel 3.2 Hasil Pengujian Koefisien Determinan

Model Summary

\begin{tabular}{|l|c|r|r|c|}
\hline Model & $\mathrm{R}$ & $\begin{array}{c}\mathrm{R} \\
\text { Square }\end{array}$ & $\begin{array}{c}\text { Adjusted } \\
\text { R Square }\end{array}$ & $\begin{array}{c}\text { Std. } \\
\text { Error of } \\
\text { the } \\
\text { Estimate }\end{array}$ \\
\hline 1 & $.734^{\mathrm{a}}$ & 0.538 & 0.451 & 1.64388 \\
\hline
\end{tabular}

a. Predictors: (Constant), Pelayanan

Sumber: Hasil pengolahan Data SPSS

Nilai Koefisien determinasi (R Square) dapat dipakai untuk memprediksi seberapa besar kontribusi pengaruh variabel bebas $(\mathrm{X})$ terhadap variabel terkait $(\mathrm{Y})$. Dari tabel 3.2 hasil perhitungan regresi dapat diketahui bahwa koefisien determinan yang diperoleh sebesar 0,538. Hal ini berarti Kualitas pelayanan kecamatan memberikan kontribusi sebesar $53,8 \%$ terhadap terhadap kepuasan masyarakat Dolok Batu Nanggar Kabupaten Simalungaun. Sedangkan sisanya yaitu $46.2 \%$ dipengaruhi oleh variabel-variabel lainnya yang tidak diteliti dalam penelitian ini.

\section{KESIMPULAN}

Hasil penelitian ini menunjukkan bahwa kepuasan pelayanan kecamatan dipengaruhi oleh dimensi kualitas jasa yaitu bukti fisik, kehandalan, daya tanggap, jaminan dan kepedulian. Terdapat pengaruh positif yang signifikan antara layanan kecamatan terhadap kepuasan masyarakat Dolok Batu Nanggar Kabupaten Simalungun. Hal ini diperoleh berdasarkan analisis regresi linier sederhana, hasil uji koefisien determinan perhitungan statistik nilai $\mathrm{F}$ hitung $=5.684$ dengan taraf significan hitung 0.019 dengan nilai Sig hitung $0.019<\mathrm{Sig}$ tabel 0.05 . Sehingga semakin besar kualitas layanan yang diberikan maka akan semakin tinggi kepuasan masyarakat Dolok Batu Nanggar Kabupaten Simalungun.

Besarnya pengaruh kualitas pelayanan kecamatan terhadap kepuasan masyarakat Dolok Batu Nanggar Kabupaten Simalungun sebesar $53,8 \%$, sedangkan sisanya yaitu $46.2 \%$ dipengaruhi oleh variabel lainnya yang tidak diteliti dalam penelitian ini.

\section{Saran}

Diharapkan kantor Kecamatan Dolok Batu Nanggar perlu memperhatikan kualitas pelayanan kepada masyarakat agar masyarakat merasa nyaman. Jika pelayanan yang diberikan semakin baik maka citra dan kinerja kecamatan akan dianggap positif. Untuk kredibilitas dan bukti fisik sudah sangat baik menurut pendapat masyarakat sehingga terus dipertahankan, sedangkan untuk daya tanggap, kepedulian dan jaminan perlu ditingkatkan sehingga masyarakat dapat merasa puas. Peningkatan pelayanan terhadap masyarakat tersebut dapat dilakukan seperti pemberian pelatihan-pelatihan kepada para pegawai

Perlunya dilakukan penelitian lanjutan dengan menggali variabel lain yang mempengaruhi pelayanan di Kecamatan seperti relationship management, atau loyalitas. 


\section{REFEREENSI}

[1] Y. Eliza, "Analisis Kepuasan Masyarakat Atas Kualitas Pelayanan Kantor Kecamatan Siberut Selatan Kabupaten Kepulauan Mentawai," Pekbis J., vol. 7, no. 1, pp. 65-73, 2015, doi: 10.1017/CBO9781107415324.004.

[2] R. Yayat, "Kualitas Pelayanan Publik Bidang Administrasi Kependudukan Di Kecamatan Pasir Jambu," J. Ilm. Magister Ilmu Adm., vol. 1, no. 2, pp. 56-65, 2017.

[3] S. Sirait, "Motivasi Sebagai Faktor Peningkatan Kinerja Kepolisian," $J$. $E K \& B I$, vol. 2, no. 1, pp. 167-177, 2019.

[4] H. M. P. Simarmata, D. Y. Saragih, and N. J. Panjaitan, "Peningkatan Kualitas Layanan Untuk Kepuasan Pelanggan Hotel," J. EK\&BI, vol. 1, no. 1 , pp. 43-51, 2018, doi: ISSN 2621-4695.

[5] Y. Trisusanti, "Pengaruh Kualitas Pelayanan dan Kepercayaan Terhadap Loyalitas Nasabah (Studi Pada Bank BNI Syariah Kantor Cabang Pekanbaru)," Jom Fisip, vol. 4, no. 2, pp. 1-16, 2017, doi: ISSN: 2355-6919.

[6] E. Haryanto, "Kualitas Layanan, Fasilitas Dan Harga Pengaruhnya Terhadap Kepuasan Pengguna Jasa Layanan Pada Kantor Samsat Manado," J. Ris. Ekon. Manajemen, Bisnis dan Akunt., vol. 1, no. 3, pp. 750-760, 2013, doi: 10.35794/emba.v1i3.2212.

[7] H. M. P. Simarmata, "PENGARUH KUALITAS JASA, CITRA PERUSAHAAN DAN TINGKAT SUKU BUNGA KREDIT TERHADAP KEPUTUSAN PENGAMBILAN PRODUK KREDIT MIKRO," Murni Sadar, vol. 7, no. 1, pp. 16-31, 2017.

[8] U. Sriwidodo and R. T. Indriastuti, "Pengaruh Dimensi Kualitas Pelayanan Jasa terhadap Kepuasan Nasabah," J. Ekon. dan Kewirausahaan, vol. 10, no. 2, pp.
164-173, 2010.

[9] Suandi, "Analisis Kepuasan Masyarakat Terhadap Pelayanan Publik Berdasarkan Indeks Kepuasan Masyarakat Di Kantor Kecamatan Belitang Kabupaten Oku Timur," J. Ilmu Adm. dan Stud. Kebijak., vol. 1, no. 2, pp. 13-22, 2019, doi: ISSN 2654-3141.

[10] P. D. Cahyani, "Tingkat Kepuasan Nasabah Terhadap Kualitas Layanan Perbankan Syariah di Yogyakarta," Esensi J. Bisnis dan Manaj., vol. 6, no. 2, pp. 151-162, 2016, doi: 10.15408/ess.v6i2.3570. 